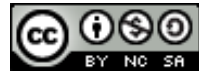

https://doi.org/10.31743/abmk.13057

\title{
WYBRANE KOLEKCJE FOTOGRAFICZNE W ZASOBACH ARCHIWUM POLSKIEJ PROWINCJI ZGROMADZENIA KSIĘŻY MISJONARZY W KRAKOWIE ORAZ ARCHIWUM INSTYTUTU WYDAWNICZEGO KSIĘŻY MISJONARZY „NASZA PRZESZLOŚĆ” W KRAKOWIE
}

\begin{abstract}
Streszczenie
Celem artykułu jest przybliżenie niektórych kolekcji fotograficznych zgromadzonych w zasobie Archiwum Polskiej Prowincji Zgromadzenia Księży Misjonarzy w Krakowie oraz Archiwum Instytutu Wydawniczego Księży Misjonarzy „Nasza Przeszłość” w Krakowie. W obydwu instytucjach obok materiałów aktowych, geodezyjno-kartograficznych i technicznych nie brak także fotografii. Są wśród nich zarówno pojedyncze zdjęcia dokumentujące życie członków Zgromadzenia Misji, jak i historię misjonarskich placówek. Jednak spotkamy tam także albumy oraz pudełka, w których zgromadzono fotografie uporządkowane według kategorii tematycznych. W większości przypadków trudno dzisiaj wskazać ich autorów. Wyjątkiem są kolekcje znajdujące się w zasobie Archiwum „Naszej Przeszłości”. Jest to dzieło jego założyciela, ks. prof. Alfonsa Schletza CM, który przez wiele długich lat zbierał rozmaite zdjęcia, aby z czasem stworzyć z nich wiele różnych kolekcji.

Słowa kluczowe: misjonarze św. Wincentego à Paulo; Archiwum Polskiej Prowincji Zgromadzenia Księży Misjonarzy; Archiwum Instytutu Wydawniczego Księży Misjonarzy „Nasza Przeszłość”; fotografie; zdjęcia; albumy; kolekcje

$* * * * *$
\end{abstract}

Historyk nieustannie w swoich badaniach ma do czynienia z różnymi źródłami. Najczęściej analizuje źródła pisane o charakterze narracyjno-relacyjnym, często również korzysta ze źródeł normatywnych, a także z licznych źródeł niespisanych: ikonograficznych, symbolicznych i materialnych.

* Ks. Wacław Umiński CM - dr teologii w zakresie historii Kościoła, adiunkt, Instytut Historii, Uniwersytet Papieski Jana Pawła II w Krakowie

e-mail: waclaw.uminski@upjp2.edu.pl

https://orcid.org/0000-0001-6901-2454 
W artykule przyjrzymy się fotografiom, które od drugiej połowy XIX wieku. zaczęły stopniowo towarzyszyć członkom Zgromadzenia Księży Misjonarzy w wielu codziennych sytuacjach. Do dzisiaj zachowały się one w dwóch instytucjach będących pod zarządem misjonarzy: Archiwum Polskiej Prowincji Zgromadzenia Księży Misjonarzy w Krakowie oraz Archiwum Instytutu Wydawniczego Księży Misjonarzy „Nasza Przeszłość” w Krakowie.

\section{Archiwum Polskiej Prowincji Zgromadzenia Księży Misjonarzy}

Misjonarze zostali sprowadzeni do Polski przez królową Ludwikę Marię Gonzagę w 1651 r. ${ }^{1}$. Dwa lata później został utworzony dom przy kościele św. Krzyża, który w 1685 r. stał się siedzibą polskiej prowincji i miejscem urzędowania wizytatora, tzn. przełożonego prowincji². W kancelarii wizytatora oprócz bieżących akt znajdowały się prawdopodobnie także dokumenty historyczne ${ }^{3}$. Taki stan przetrwał aż do kasaty zgromadzenia w $1864 \mathrm{r}$. w zaborze rosyjskim ${ }^{4}$. Formalnie archiwum zostało utworzone w Krakowie na Kleparzu, gdzie od 1865 r. mieściła się nowa siedziba prowincji ${ }^{5}$. Gdy w $1912 \mathrm{r}$. przeniesiono zarząd prowincji do domu Stradomskiego, tam również umieszczono archiwum ${ }^{6}$.

W skład zasobu archiwum prowincjalnego, liczącego ok. 400 m.b. akt z XV-XX wieku, wchodzą m.in. akta kancelarii kolejnych wizytatorów, akta po dawnych prowincjach skasowanych przez zaborców: warszawskiej (1685-1864) i litewskiej (1794-1842), po prowincji krakowskiej (od 1918 polskiej), po wiceprowincjach amerykańskiej, brazylijskiej i rumuńskiej, a także dokumentacja misji chińskiej (1929-1949), spuścizna członków zgromadzenia, dokumentacja seminariów diecezjalnych będących pod zarządem misjonarzy oraz stowarzyszeń wincentyńskich ${ }^{7}$. Dokumenty przechowywane w tym archiwum zostały podzielone

${ }^{1}$ Misja Polska w pismach Wincentego a Paulo i Ludwiki de Marillac, t. 1, Kraków 2010, s. $30-32$.

${ }^{2}$ Misjonarze św. Wincentego a Paulo w Polsce (1651-2001), t. 1, Dzieje, red. S. Rospond, Kraków 2001, s. 60-61, 70.

${ }^{3}$ M. Lange, Archiwum Zgromadzenia Księży Misjonarzy w Krakowie, „Archiwariusz. Biuletyn Archiwum Archidiecezjalnego w Poznaniu”, 2007 nr 3 [druk 2009], s. 132.

${ }^{4}$ Ł. Janczak, Wspomnienie ostatnich chwil istnienia w Polsce Zgromadzenia Księży Misjonarzy w Domu Głównym przy kościele św. Krzyża w Warszawie, „Roczniki Obydwóch Zgromadzeń”, 1900 s. 11-20; Misjonarze św. Wincentego a Paulo w Polsce, s.173-176.

${ }^{5}$ Por. S. Janaczek, Powstanie i organizacja Krakowskiej Prowincji Księży Misjonarzy (18651914), „Nasza Przeszłość”, 86 (1996) s. 361-432; W. Umiński, Archiwum Prowincji Polskiej Zgromadzenia Księży Misjonarzy w Krakowie, „Archiva Ecclesiastica”, (2005) nr 2, s. 67.

${ }^{6}$ Por. Misjonarze św. Wincentego a Paulo w Polsce, s. 250; Lange, Archiwum Zgromadzenia Księży Misjonarzy w Krakowie, s. 132.

${ }^{7}$ J. Michalewicz J., Wstęp, w: Katalog archiwum polskiej prowincji Zgromadzenia Księży Misjonarzy św. Wincentego a Paulo, t. 1, Kraków 2014, s. XI-XVI; Katalog zabytków sztuki w Polsce, t. 4, Miasto Kraków, cz. 5, Kazimierz i Stradom, Kościoły i klasztory, 2, red. I. Reduch-Samkowa, J. Samek, Warszawa 1994, s. 58-59; Umiński, Archiwum Prowincji Polskiej, s. 68. 
na dziewięć działów akt, wewnętrznie zróżnicowanych na zespoły odpowiadające sferom działania Zgromadzenia ${ }^{8}$.

Misjonarze, podobnie jak inne wspólnoty zakonne, gromadzili spuścizny zmarłych współbraci. Niewątpliwie w początkowym okresie zdjęcia pojawiały się bardzo rzadko. Najczęściej były to pojedyncze fotografie zwane legitymacyjnymi. Obok nich spotkamy również fotografie okolicznościowe. Dla ilustracji powyższej praktyki przykładowo można wskazać na teczki personalne następujących misjonarzy: ks. Kaspra Słomińskiego $\mathrm{CM}^{9}$, ks. Józefa Kryski $\mathrm{CM}^{10}$, ks. Józefa Barona $\mathrm{CM}^{11}$, ks. Czesława Lewandowskiego $\mathrm{CM}^{12}$, ks. Konstantego Michalskiego $\mathrm{CM}^{13}$, ks. Wilhelma Michalskiego $\mathrm{CM}^{14}$ czy Hieronima Feichta $\mathrm{CM}^{15}$.

${ }^{8}$ Są to następujące działy: I - Akta władz centralnych Polskiej Prowincji Zgromadzenia Księży Misjonarzy; II - Domy Polskiej i Litewskiej Prowincji; III - Misje ludowe oraz Zagraniczne placówki Polskiej Prowincji; IV - Katalogi, spisy zmarłych, księgi inkorporacji, księgi ślubów i biogramy; V - Spuścizny księży misjonarzy i osób związanych ze Zgromadzeniem; VI - Rodzina Wincetyńska; VII - Szkoły i seminaria; VIII - Materiały do wykładów i prac naukowych prowadzonych przez misjonarzy; IX - Zbiory specjalne. Warto wyjaśnić, że wyszczególnione powyżej działy dzielą się na wiele zespołów. Por. Michalewicz, Katalog archiwum, t. 1, s. XV, XVII-XIX.

${ }^{9}$ Kasper Słomiński (1869-1929), wstąpił do Zgromadzenia w 1886 r., święcenia kapłańskie przyjął w 1892 r., wizytator Polskiej Prowincji Zgromadzenia Misji w latach 1906-1925, Archiwum Polskiej Prowincji Zgromadzenia Księży Misjonarzy (dalej AMS), sygn. V/POL 127, Spuścizna ks. Kaspra Słomińskiego. Zob. W. Umiński, Polska Prowincja Zgromadzenia Księży Misjonarzy w latach 1918-1939, Kraków 2009, s. 288.

${ }^{10}$ Józef Kryska (1869-1957), wstąpił do Zgromadzenia w 1887 r., święcenia kapłańskie przyjął w 1894 r., wizytator Polskiej Prowincji Zgromadzenia Misji w latach 1925-1957. AMS, sygn. V/ POL 259, Spuścizna ks. Józefa Kryski. Zob. Umiński, Polska Prowincja, s. 280.

${ }^{11}$ Józef Baron (1895-1976), wstąpił do Zgromadzenia w 1913 r., święcenia kapłańskie przyjął w 1920 r. AMS, sygn. V/POL 344, Spuścizna ks. Józefa Barona. Zob. Umiński, Polska Prowincja, s. 271.

${ }^{12}$ Czesław Lewandowski (1864-1934), wstąpił do Zgromadzenia w 1884 r., święcenia kapłańskie przyjął w 1889 r. AMS, sygn. V/POL 135 Spuścizna ks. Czesława Lewandowskiego. Zob. Umiński, Polska Prowincja, s. 281.

${ }^{13}$ Konstanty Michalski (1879-1947), wstąpił do Zgromadzenia w 1896 r., święcenia kapłańskie przyjął w 1903 r. AMS, sygn. V/POL 236, Spuścizna ks. Konstantego Michalskiego. Zob. Umiński, Polska Prowincja, s. 282.

${ }^{14}$ Wilhelm Michalski (1879-1943), wstąpił do Zgromadzenia w 1896 r., święcenia kapłańskie przyjął w 1903 r. AMS, sygn. V/POL 198, Spuścizna ks. Wilhelma Michalskiego. Zob. Umiński, Polska Prowincja, s. 282.

${ }^{15}$ Hieronim Feicht (1894-1967), wstąpił do Zgromadzenia w 1909 r., święcenia kapłańskie przyjął w 1919 r., AMS, sygn. V/POL 305, Spuścizna ks. Hieronima Feichta. Zob. Umiński, Polska Prowincja, s. 275. 


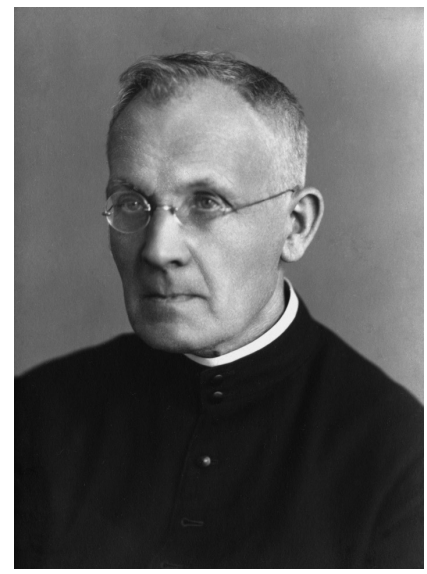

Il. 1. ks. Józef Kryska CM

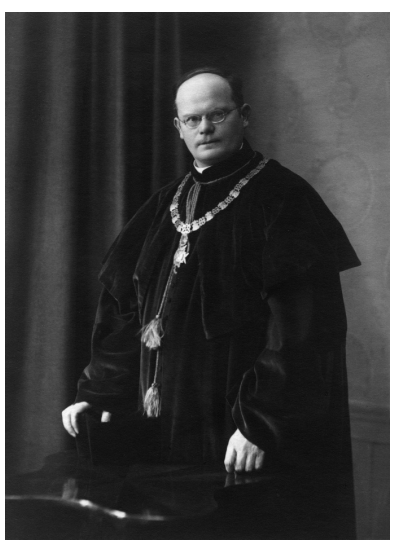

Il. 3. ks. Konstanty Michalski CM

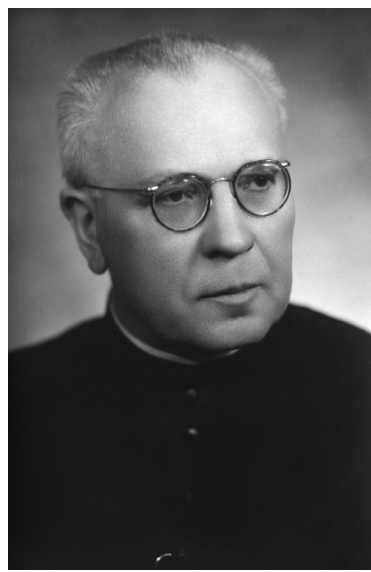

Il. 2. ks. Józef Baron CM

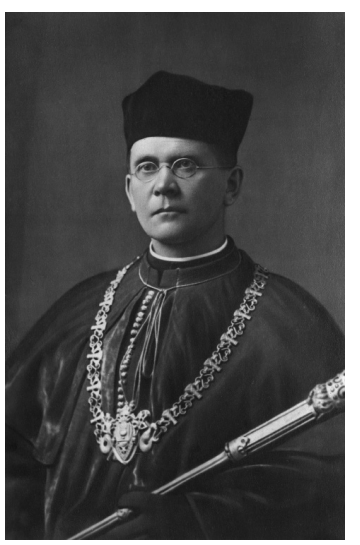

Il. 4. ks. Wincenty Michalski CM

Obok fotografii przedstawiających konkretnych misjonarzy w archiwum prowincjalnym spotkamy również zdjęcia grupowe. Przedstawiają one nie tylko kapłanów czy braci, ale także kleryków i kandydatów do Zgromadzenia. Większość z nich została zgromadzona w dokumentacji placówek edukacyjnych i formacyjnych, takich jak Małe Seminarium ${ }^{16}$, Gimnazjum ${ }^{17}$ i Seminarium Internum ${ }^{18}$.

Ciekawym przykładem z powyżej grupy są zdjęcia prezentujące orkiestry kleryków z Małych Seminariów prowadzonych przez Księży Misjonarzy w Krakowie na Nowej Wsi, w Krakowie na Kleparzu oraz w Wilnie. Są one bardzo waż-

${ }^{16}$ AMS, sygn. VII.4/XVIII, Małe Seminarium Zgromadzenia Księży Misjonarzy. Zdjęcia.

${ }^{17}$ AMS, sygn. VII.5/19, Gimnazjum Wyższe Męskie Zgromadzenia Księży Misjonarzy. Zdjęcia uczniów i nauczycieli.

${ }^{18}$ Odpowiednik Nowicjatu w większości wspólnot zakonnych. AMS, sygn. VII.3/XV, Seminarium Internum Zgromadzenia Księży Misjonarzy. Zdjęcia. 
nym dokumentem dla badaczy zajmujących się historią muzyki w seminariach duchownych ${ }^{19}$.

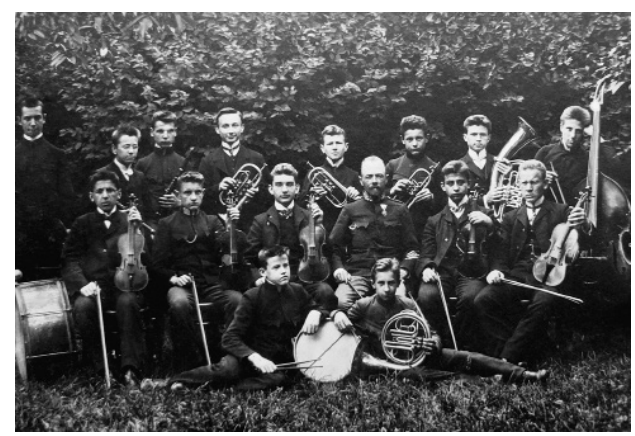

I1. 5. Orkiestra małoseminarzystów w Krakowie na Stradomiu (1909)

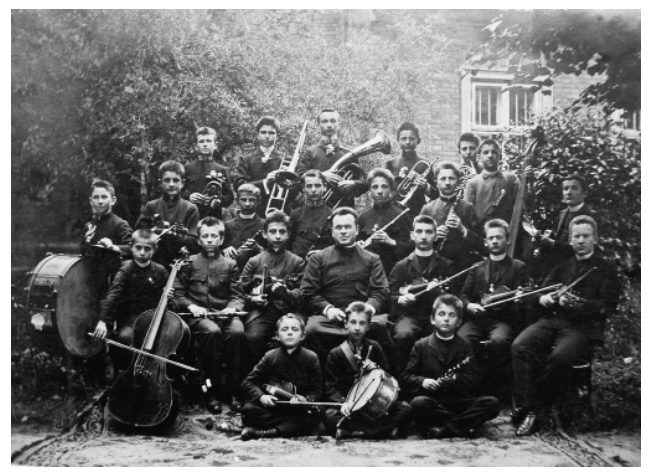

Il. 6. Orkiestra małoseminarzystów w Krakowie na Nowej Wsi (1910)

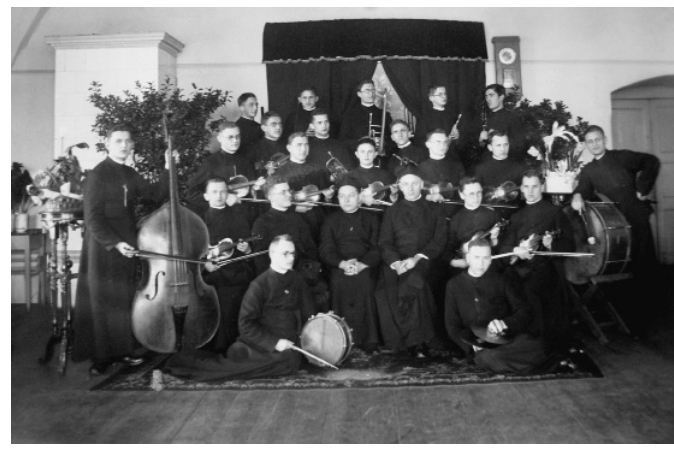

Il. 7. Orkiestra klerycka w Wilnie (1933)

${ }^{19}$ Spotkamy tam np. zdjęcia orkiestry małoseminarzystów podczas ćwiczeń zarówno w salach lekcyjnych, jak i podczas wspólnych wypraw do lasu. Autor pracy omawiającej dokonania Zgromadzenia Księży Misjonarzy na niwie muzycznej bardzo często odwoływał się do zdjęć przedstawiających orkiestry i chóry prowadzone przez misjonarzy. Por. W. Kałamarz, Muzyka u misjonarzy. Wkład Zgromadzenia Księży Misjonarzy św. Wincentego a Paulo, Kraków 2009. 
Obok wymienionych instytucji trzeba wskazać też na prowadzony przez misjonarzy Zakład im. Ks. Siemaszki dla biednych i opuszczonych chłopców. Wśród obfitej dokumentacji aktowej znajdziemy wiele zdjęć dokumentujących działalność tego ośrodka ${ }^{20}$.

Kolejną ważną grupą są fotografie, najczęściej pojedyncze, prezentujące placówki prowadzone przez Zgromadzenie Księży Misjonarzy. Spotkamy je w zespołach następujących domów misjonarskich: Bydgoszcz ${ }^{21}$, Kraków-Stradom ${ }^{22}$, Kraków-Kleparz ${ }^{23}$, Kraków-Nowa Wieś24, Lwów ${ }^{25}$, Milatyn Nowy ${ }^{26}$, Odporyszów $^{27}$, Tarnów ${ }^{28}$, Warszawa ${ }^{29}$, Wilno ${ }^{30}$ i Zakopane ${ }^{31}$.

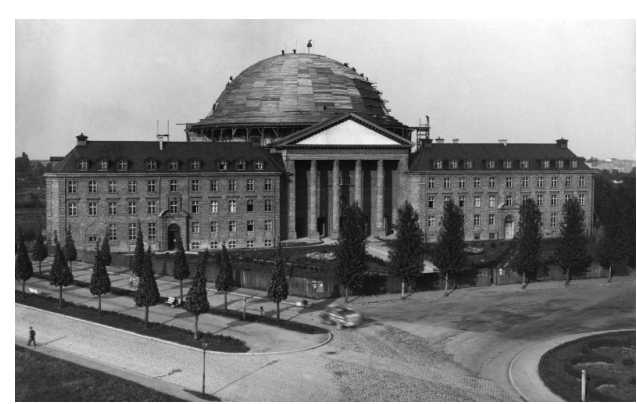

Il. 8. Bydgoszcz - dom i kościół pw. św. Wincentego a Paulo

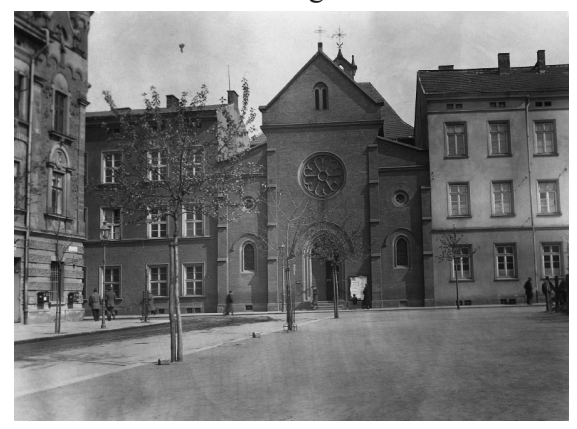

Il. 10. Kraków - Kleparz - dom i kościół pw. Św. Wincentego a Paulo

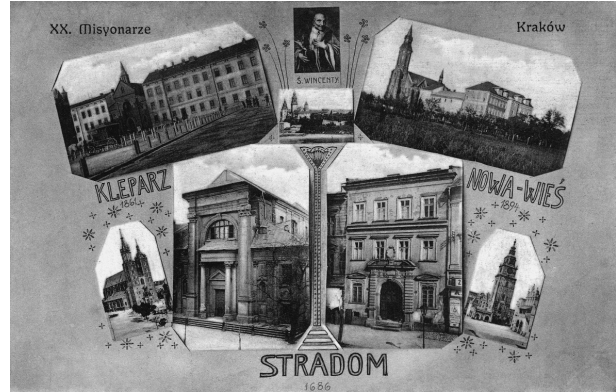

Il. 9.Placówki misjonarskie w Krakowie

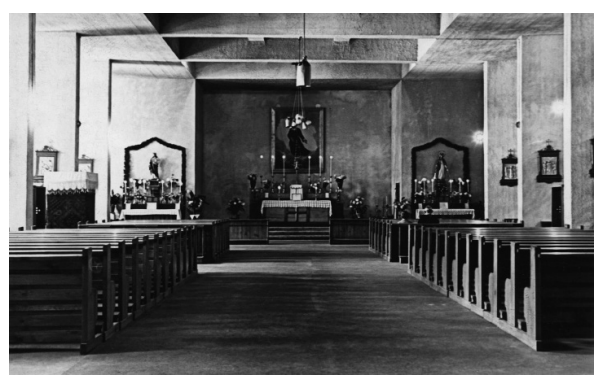

Il. 11. Lwów - dom misjonarski

${ }^{20}$ AMS, sygn. VII.7/XII H, Zakład Młodzieży Męskiej im. Ks. Kazimierza Siemaszki. Zakład w Czernej. Fotografie.

${ }^{21}$ AMS, sygn. II.1/010/VI, Bydgoszcz - Akta Domu Zgromadzenia. Zdjęcia.

${ }^{22}$ AMS, sygn. II.1/043/V.22.7, Kraków-Stradom - Akta Domu Zgromadzenia. Zdjęcia.

${ }^{23}$ AMS, sygn. II.1/044/IV, Kraków-Kleparz - Akta Domu Zgromadzenia. Zdjęcia.

${ }^{24}$ AMS, sygn. II.1/045/V.14, Kraków-Nowa Wieś - Akta Domu Zgromadzenia. Zdjęcia.

${ }^{25}$ AMS, sygn. II.1/062/VIII.7, Lwów - Akta Domu Zgromadzenia. Zdjęcia.

${ }^{26}$ AMS, sygn. II.1/068/I.32, Milatyn Nowy - Akta Domu Zgromadzenia. Zdjęcia.

${ }^{27}$ AMS, sygn. II.1/075/I.13, Odporyszów - Akta Domu Zgromadzenia. Zdjęcia.

${ }^{28}$ AMS, sygn. II.1/108/XXIII, Tarnów - Akta Domu Zgromadzenia. Zdjęcia.

${ }^{29}$ AMS, sygn. II.1/111/XII, Warszawa - Akta Domu Zgromadzenia. Zdjęcia.

${ }^{30}$ AMS, sygn. II.1/116/VI, Wilno - Akta Domu Zgromadzenia. Zdjęcia.

${ }^{31}$ AMS, sygn. II.1/123/I.14, Zakopane - Akta Domu Zgromadzenia. Zdjęcia. 


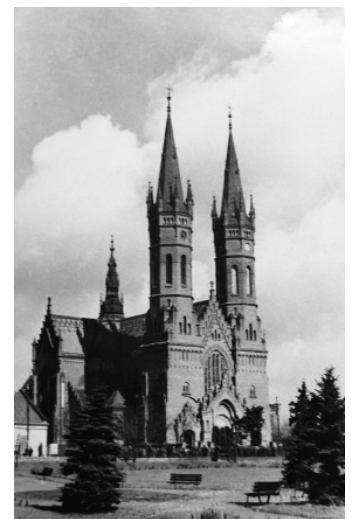

Il. 12. Tarnów - kościół pw. Św. Rodziny

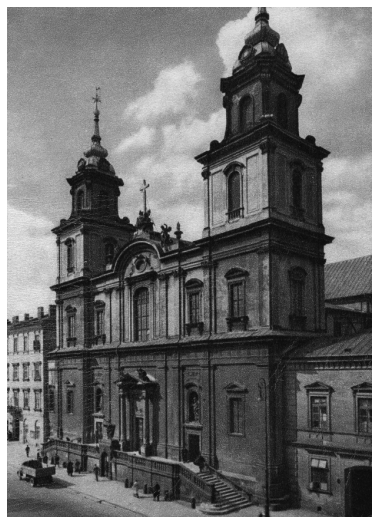

Il. 13. Warszawa - kościół pw. Św. Krzyża

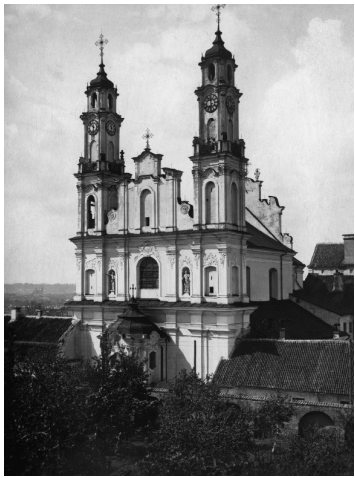

Il. 14. Wilno - kościół pw.

Wniebowstąpienia Pańskiego

W tej grupie obok pojedynczych zdjęć znajdziemy również kilka albumów. Istotnym albumem jest ten, który przedstawia nieistniejącą już placówkę misjonarską w Warszawie - Konwikt Teologiczny Świętego Krzyża ${ }^{32}$. Zdjęcia w nim zebrane mogą pomóc osobom zainteresowanym historią Konwiktu zarówno dowiedzieć się o wyglądzie zewnętrznym i układzie pomieszczeń, jak i zobaczyć osoby związane z tą instytucją $a^{33}$.

${ }^{32}$ AMS, sygn. II.1/111/X.14, Warszawa - Akta Domu Zgromadzenia. Konwikt Teologiczny. Zdjęcia

${ }^{33}$ Zdjęcia $\mathrm{z}$ tego albumu zostały wykorzystane jako materiał ilustracyjny w publikacji przedstawiającej historię konwiktu. Por. Umiński, Konwikt Teologiczny Świętego Krzyża w Warszawie w latach 1918-1939, Kraków 2017. 


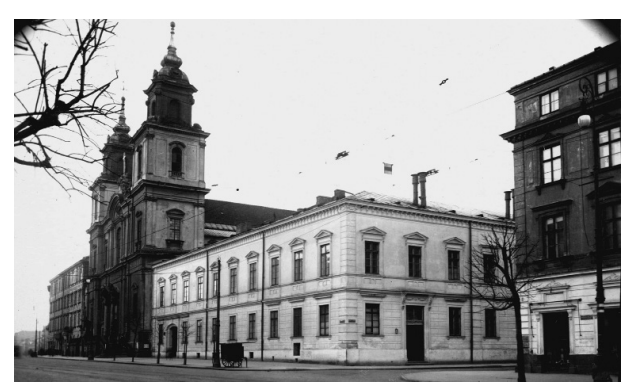

I1. 15. Warszawa - Konwikt Teologiczny Św. Krzyża od strony Krakowskiego Przedmieścia

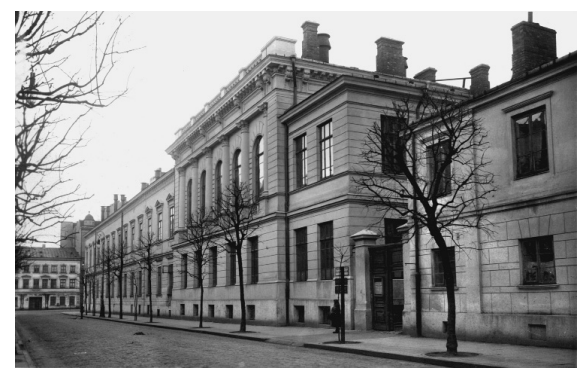

Il. 16. Warszawa - Konwikt Teologiczny Św. Krzyża od strony ul. Traugutta

Kończąc omawianie zbiorów fotograficznych w Archiwum Prowincjalnym, trzeba zwrócić uwagę na dział specjalny ${ }^{34}$. Jedną z części tego działu są zdjęcia podzielone na trzy grupy. W pierwszej z nich znalazły się fotografie w 23 albumach, przedstawiające osoby ${ }^{35}$, miejscowości ${ }^{36}$ oraz zdarzenia $^{37}$. W skład drugiej weszły zdjęcia niezidentyfikowane, zebrane w 15 pudłach i 16 albumach ${ }^{38}$. Ostatnia grupa składa się z 6 drewnianych pudeł, w których zgromadzono ok. 300 klisz szklanych prezentujących misje w Chinach, Japonii i Korei ${ }^{39}$.

${ }^{34} \mathrm{~W}$ dziale umieszczono m.in. plany kościołów, budynków i parcel, mapy i plany, drukowane ryciny i plansze, zdjęcia, przeźrocza, taśmy magnetofonowe i filmowe, mikrofilmy. W zbiorze zdjęć część wymaga dalszych prac mających na celu ich identyfikację. Por. J. Michalewicz, Katalog archiwum, t. 2, Kraków 2018, s. 761-800.

${ }^{35}$ Wśród 340 osób znajdziemy zdjęcia m.in. kard. Albina Dunajewskiego, kard. Adama Stefana Sapiehy, abpa Edwarda Likowskiego, bpa Jana Lorka CM, bpa Ignacego Krauzego CM, bpa Karola Wojtyły oraz bpa Karola Pękali. AMS, sygn. IX.9 A. Zdjęcia zidentyfikowane - osoby. Por. Michalewicz, Katalog polskiej prowincji, t. 2, s. 795-797.

${ }^{36} \mathrm{~W}$ omawianych albumach można spotkać ok. 80 zdjęć miejscowości z Brazylii, Francji, Polski, Rumunii i Stanów Zjednoczonych. Wiele z nich związanych jest z posługą misjonarzy św. Wincentego à Paulo. AMS, sygn. IX.9 A, Zdjęcia zidentyfikowane - miejscowości. Por. Michalewicz, Katalog polskiej prowincji, t. 2, s. 795-797.

${ }^{37}$ We wspomnianych albumach zgromadzono również ok. 80 zdjęć dokumentujących ważne wydarzenia z życia Kościoła w Polsce i za granicą. Głównie dotyczą one kandydatów i członków Zgromadzenia Misji. AMS, sygn. IX.9 A, Zdjęcia zidentyfikowane - zdarzenia. Por. Michalewicz, Katalog polskiej prowincj, t. 2, s. 798.

${ }^{38}$ AMS, sygn. IX.9 B, Zdjęcia niezidentyfikowane. Por. Michalewicz, Katalog polskiej prowincji, t. 2, s. 798-799.

${ }^{39}$ AMS, sygn. IX.9 C, Klisze szklane z misji. Por. Michalewicz, Katalog polskiej prowincji, t. 2, s. 799 . 


\section{Archiwum Instytutu Wydawniczego Księży Misjonarzy „Nasza Przeszlość”}

Obok Archiwum Prowincjalnego pod opieką Księży Misjonarzy znajduje się także Archiwum Instytutu Wydawniczego Księży Misjonarzy „Nasza Przeszłość”. Jego powstanie związane jest z osobą ks. dra hab. Alfonsa Schletza $\mathrm{CM}^{40}$, który w 1946 r. rozpoczął wydawanie czasopisma historycznego „Nasza Przeszłość”. Studia z dziejów Kościoła i kultury katolickiej w Polsce”. Jednocześnie utworzył archiwum i bibliotekę, które stały się podwalinami nowej placówki naukowej. Na początku siedziba Instytutu Wydawniczego, Redakcja i Archiwum zostały zorganizowane w Domu Prowincjalnym Księży Misjonarzy przy ul. Stradom. W 1972 r. Instytut uzyskał nową lokalizację przy ul. Strzelnica w Krakowie. W 2004 r. Archiwum wraz z Redakcją zostało ponownie umieszczone w pierwotnej siedzibie ${ }^{41}$.

W skład archiwum „Naszej Przeszłości”, liczącego ok. 40 m.b. akt z okresu od XVIII do XX wieku wchodzą m.in. dokumenty dotyczące życia i działalności naukowej oraz dydaktycznej ks. Alfonsa Schletza, materiały związane zadministracją i redakcją Instytutu Wydawniczego, akta dotyczące historii Kościoła, kultury katolickiej w Polsce oraz historii teologii ${ }^{42}$.

Podobnie jak w Archiwum Prowincjalnym, w Archiwum „Naszej Przeszłości” spotkamy materiały fotograficzne. Są one równie bogate i interesujące. Niewątpliwie jest to zasługa założyciela Archiwum. Dzięki jego wieloletniej pracy udało mu się zgromadzić wiele cennych fotografii. Zdjęcia zostały naklejone na karty formatu A5 i opatrzone stosownymi opisami, a następnie złożone w kartonowych pudełkach. Ksiądz Alfons Schletz uporządkował fotografie według określonego klucza. Po pierwsze oddzielił zdjęcia postaci od zdjęć budynków i miejscowości. W obydwu kategoriach dokonał kolejnych wewnętrznych podziałów. Trudno w krótkim tekście omówić wszystkie kolekcje stworzone przez założyciela „Naszej Przeszłości”. Do artykułu zostały wybrane tylko niektóre, pokazujące jednak bogactwo zbiorów fotograficznych ${ }^{43}$.

Wśród zdjęć postaci można przede wszystkim wskazać fotografie indywidualnych osób. Przedstawiają one zarówno osoby duchowne, jak i świeckie. Fotografie duchownych zostały zebrane w kilku pudełkach. Zawierają on zdjęcia kapłanów, biskupów i papieży. Najczęściej są to pojedyncze zdjęcia ${ }^{44}$. W przypadku

${ }^{40}$ Alfons Schletz (1911-1981), święcenia kapłańskie przyjął w 1936 r., historyk, wykładowca historii i misjologii w Instytucie Teologicznym Księży Misjonarzy w Krakowie, założyciel i pierwszy redaktor „Naszej Przeszłości”. Por. W. Umiński, Schletz Alfons, w: Encyklopedia katolicka, t. 17, red. E. Gigilewicz, Lublin 2012, kol. 1243-1244.

${ }^{41}$ B. Krasnowolski, Dwie siedziby „Naszej Przeszłości”, w: Sto tomów „Naszej Przeszłości”. Bibliografia, dzieje, ludzie, red. J. Dukała, Kraków 2003, s. 337-340.

${ }^{42}$ Szerzej o zbiorach archiwum zob. Gromadzenie $i$ charakterystyka zbiorów w Archiwum „Naszej Przeszłości”, w: Zabezpieczanie i udostępnianie archiwalnych zasobów kościelnych, red. A. Laszuk, Warszawa 2016, s. 148-158.

${ }^{43} \mathrm{~W}$ chwili pisania artykułu trwały prace inwentaryzacyjne w Archiwum „Naszej Przeszłości”. Podczas wspomnianych działań jednostkom nadano numery topograficzne. Docelowo każda jednostka będzie miała sygnaturę.

${ }^{44}$ Por. Archiwum Instytutu Wydawniczego Księży Misjonarzy „Nasza Przeszłość” (dalej: ANP), nr top. 0003/1-57, Zbiór fotografii. Fotografie duchownych - indywidualne. 
kilku osób zachowało się więcej fotografii. Dotyczy to szczególnie kolekcji zatytułowanej Święci ${ }^{45}$ oraz Biskupi ${ }^{46}$. W pierwszej z nich zebrano wizerunki m.in. następujących świętych: św. Andrzeja Świerada ${ }^{47}$, św. Stanisława Papczyńskiego ${ }^{48}$, św. Stanisława Kostki ${ }^{49}$, św. o. Honorata Koźmińskiego OFMCap ${ }^{50}$, bł. Wincentego Kadłubka ${ }^{51}$. W drugiej zgromadzono zdjęcia m.in. następujących biskupów: kard. Augusta Hlonda ${ }^{52}$, kard. Stefana Wyszyńskiego ${ }^{53}$, kard. Karola Wojtyły ${ }^{54}$, abpa Bolesława Kominka ${ }^{55}$, bpa Józefa Bilczewskiego ${ }^{56}$, bpa Józefa Pelczara ${ }^{57}$.

Wśród indywidualnych zdjęć na szczególną uwagę zasługuje kolekcja zatytułowana Misjonarze. Składa się ona z 4 pudeł. Zdjęcia zostały uporządkowane alfabetycznie według nazwisk kapłanów Zgromadzenia Misji. W przypadku niektórych misjonarzy zachowało się kilka lub kilkanaście fotografii. Część pierwsza zawiera zdjęcia księży o nazwiskach rozpoczynających się na litery A-J58, część druga - litery K-M $\mathrm{M}^{59}$, część trzecia - litery N-S ${ }^{60}$, część czwarta - litery Ś- $\mathrm{Z}^{61}$.

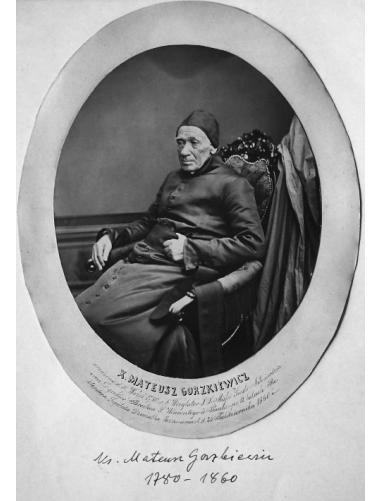

Il. 17. Ks. Mateusz Gorzkiewicz CM

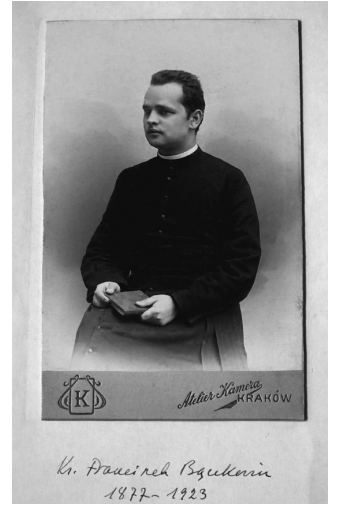

Il. 18. Ks. Franciszek Bączkowicz CM

${ }^{45}$ ANP, nr top. 0249/1-100, Zbiór fotografii. Święci (dalej Święci).

${ }^{46}$ ANP, nr top. 0252/1-105, Zbiór fotografii. Biskupi (dalej Biskupi)

${ }^{47}$ ANP, nr top. 0249/76-79, Święci - Andrzej Świerad.

${ }^{48}$ ANP, nr top. 0249 71-72, Święci - Stanisław Papczyński.

${ }^{49}$ ANP, nr top. 0249/52-55, Święci - Stanisław Kostka.

${ }^{50}$ ANP, nr top. 0249/56-61, Święci - Honorat Koźmiński.

${ }^{51}$ ANP, nr top. 0249/35-48, Święci - Wincenty Kadłubek

${ }^{52}$ ANP, nr top. 0252/9-11, Biskupi - August Hlond.

${ }^{53}$ ANP, nr top. 0252/1,4,11-13,15,19,54-74, Biskupi - Stefan Wyszyński.

${ }^{54}$ ANP, nr top. 0252/37, 40-50, Biskupi - Karol Wojtyła.

${ }^{55}$ ANP, nr top. 0252/39,79, Biskupi - Bolesław Kominek.

${ }^{56}$ ANP, nr top. 0252/24-26, Biskupi - Józef Bilczewski.

${ }^{57}$ ANP, nr top. 0252/28-31, Biskupi - Józef Pelczar.

${ }^{58} \mathrm{ANP}$, nr top. 0254/1-73, Zbiór fotografii. Misjonarze św. Wincentego à Paulo (dalej: Misjonarze), cz 1, A-J.

${ }^{59}$ ANP, nr top. 0255/1-74, Misjonarze, cz. 2, K-M.

${ }^{60}$ ANP, nr top. 0256/1-75, Misjonarze, cz. 3, N-S.

${ }^{61}$ ANP, nr top. 0257/1-46, Misjonarze, cz. 4, Ś-Z. 


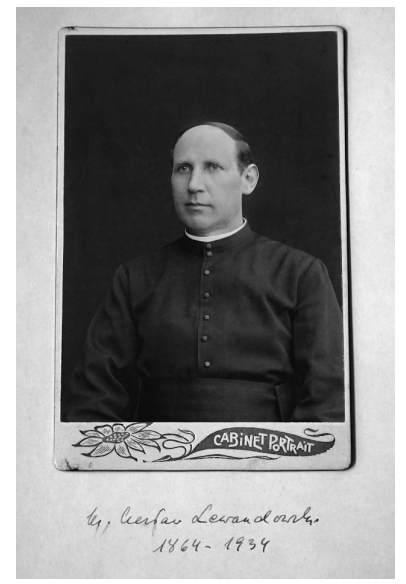

Il. 19. Ks. Czesław Lewandowski CM

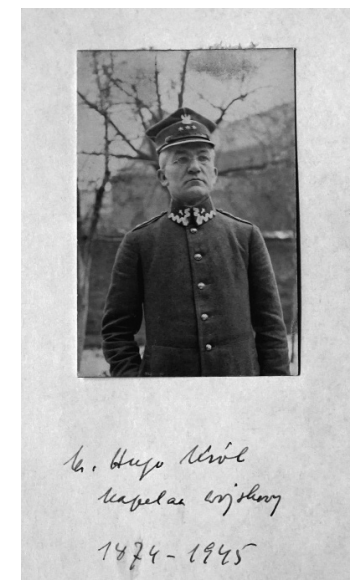

Il. 20. Ks. Hugo Król CM

Bardzo interesującą kolekcją zawierającą dokumentacją fotograficzną dotyczącą jednej osoby jest zbiór poświęcony ks. Wacławowi Szuniewiczowi CM, lekarzowi, kapłanowi i społecznikowi. Znajdziemy tam zdjęcia zarówno rodzinne, jak i z lat szkolnych. Obok zdjęć ze studiów medycznych są także fotografie z pobytu w Wyższym Seminarium Duchownym Księży Misjonarzy w Krakowie. Najwięcej zdjęć dotyczy posługi tego kapłana z czasów pracy w Chinach, USA oraz Brazyliii ${ }^{62}$.

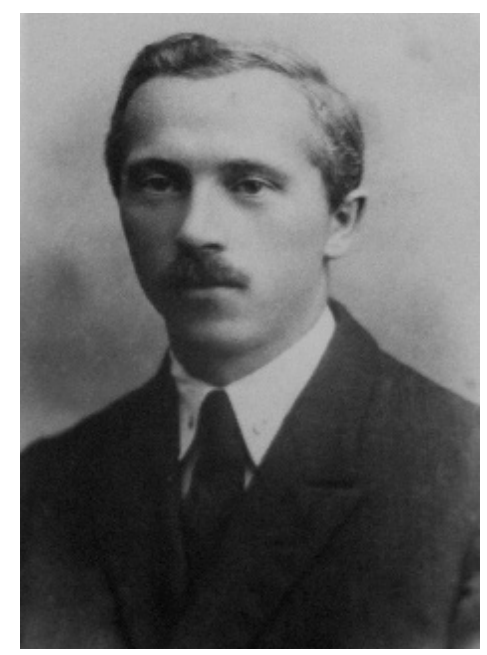

I1. 21. Ks. Wacław Szuniewicz CM po doktoracie

${ }^{62}$ ANP, nr top. 1026/1-60, Zbiór fotografii. Ksiądz Wacław Szuniewicz CM. 


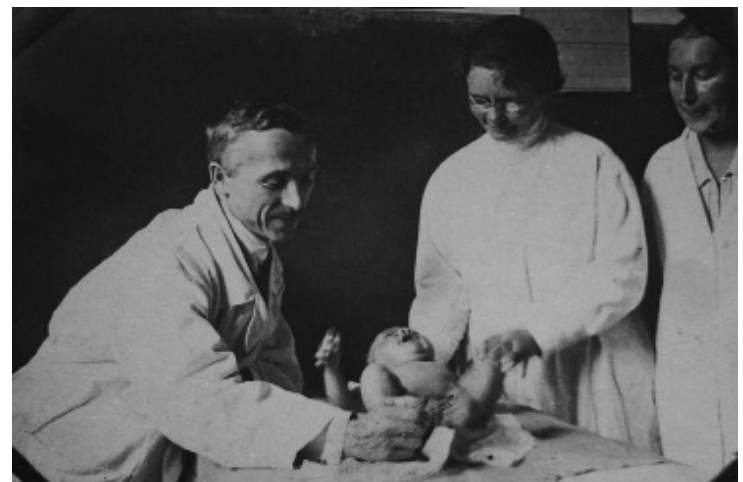

Il. 22. Ks. Wacław Szuniewicz CM - w Zakładzie Opieki

w Wilnie

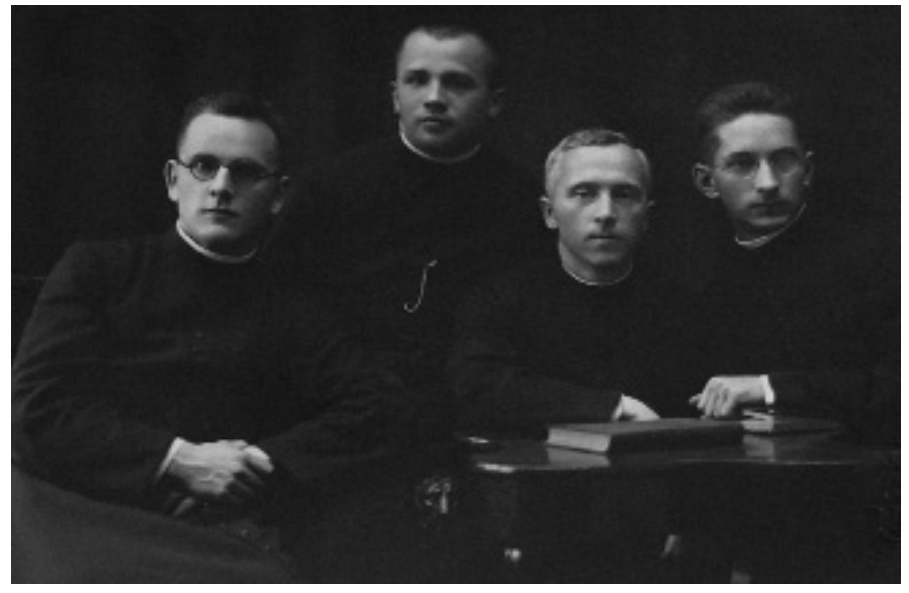

Il. 23. Ks. Wacław Szuniewicz CM - w Wyższym Seminarium Duchownym Księży Misjonarzy w Krakowie

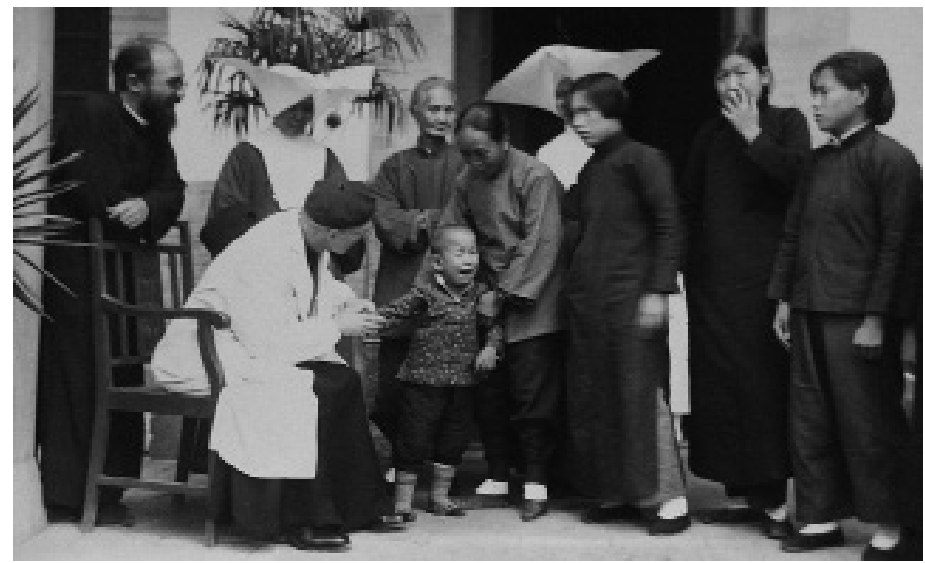

Il. 24. Ks. Wacław Szuniewicz CM - w czasie przyjmowania pacjentów w Chinach 


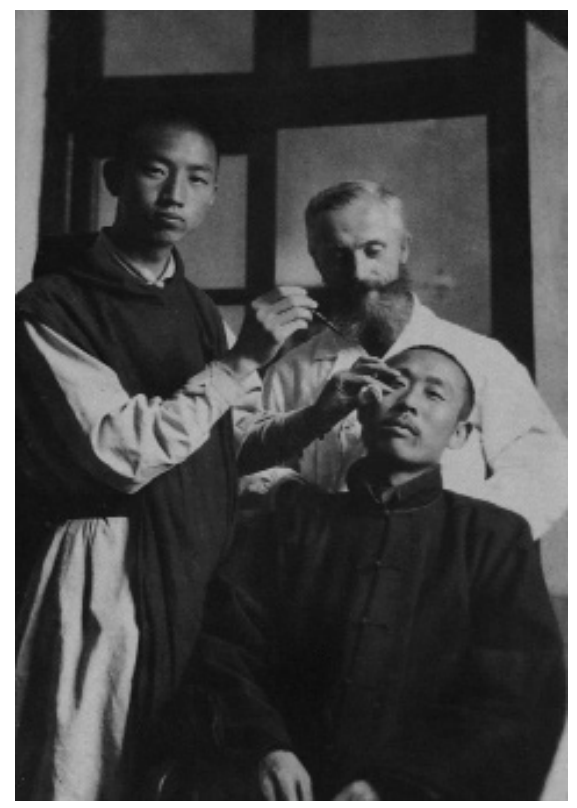

Il. 25. Ks. Wacław Szuniewicz CM - podczas pracy w szpitalu w Chinach

Jak wspomniano wyżej, odrębną grupę stanowią zdjęcia osób świeckich. Zostały one zebrane w dwóch pudłach ${ }^{63}$. Następną kategorią są zdjęcia grupowe różnych osób. Zasadniczo zebrano je w jednym pudełku oznaczonym nr top. $0006^{64}$. Jednak warto zauważyć, że część zdjęć grupowych stanowi część innych kolekcji.

Obok zdjęć indywidualnych i grupowych można spotkać też kolekcje mieszane. Pierwsza z nich to Święci i błogosławieni Rodziny Wincentyńskiej. Zebrano w niej fotografie przedstawiające fotografie indywidualne: św. Wincentego à Paulo ${ }^{65}$, św. Ludwiki de Marillac ${ }^{66}$ oraz fotografie grupowe: bł. Ludwika Józefa François i Jana Henryka Gruyera ${ }^{67}$ oraz bł. Męczenniczek z Arras ze Zgromadzenia Sióstr Miłosierdzia ${ }^{68}$.

Kolejna kolekcja to Rodzina Zamoyskich. Przedstawia ona fotografie następujących postaci: generała Władysława Zamoyskiego ${ }^{69}$, generałowej Jadwigi

${ }^{63}$ ANP, nr top. 0004/1-14, Zbiór fotografii. Fotografie różnych osób - indywidualne, cz. 1; nr top 0005/1-28 Zbiór fotografii. Fotografie różnych osób - indywidualne, cz. 2.

${ }^{64}$ ANP, nr top. 0006/1-35, Zbiór fotografii. Fotografie różnych osób - zbiorowe.

${ }^{65}$ ANP, nr top. 250/6-8, 12-13, 15-17, 19, 24-27, 31, 35-39, Zbiór fotografii. Święci i błogosławieni Rodziny Wincentyńskiej (dalej Święci Rodziny) - Wincenty à Paulo.

${ }^{66}$ ANP, nr top. 250/4-5, Święci Rodziny - Ludwika de Marillac.

${ }^{67}$ ANP, nr top. 250/1, Święci Rodziny - Ludwik François i Jan Gruyer.

${ }^{68}$ ANP, nr top. 250/2-3, Święci Rodziny - Męczenniczki z Arras.

${ }^{69}$ ANP, nr top. 253/4, Zbiór fotografii. Rodzina Zamoyskich (dalej: Rodzina Zamoyskich). Władysław Generał Zamoyski. 
Zamoyskiej $^{70}$, Andrzeja ${ }^{71}$ i Zdzisława ${ }^{72}$ Zamoyskich (braci generała), Celestynę z Zamoyskich Działyńską ${ }^{73}$, Władysława Zamoyskiego juniora ${ }^{74}$, Marię Zamoyską ${ }^{75}$. W tej kolekcji znalazły się także fotografie ukazujące działalność Zakładu Kórnickiego w Kuźnicach koło Zakopanego ${ }^{76}$.

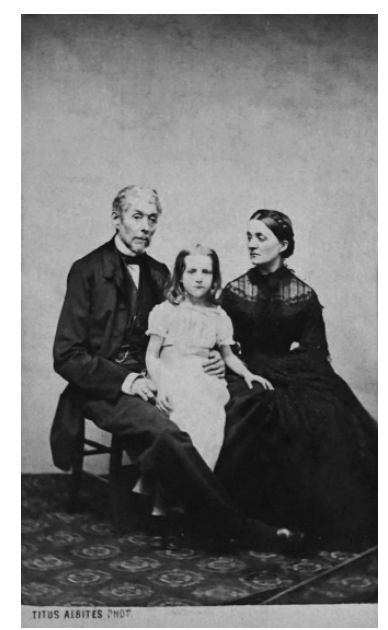

Il. 26. Rodzina

Zamoyskich

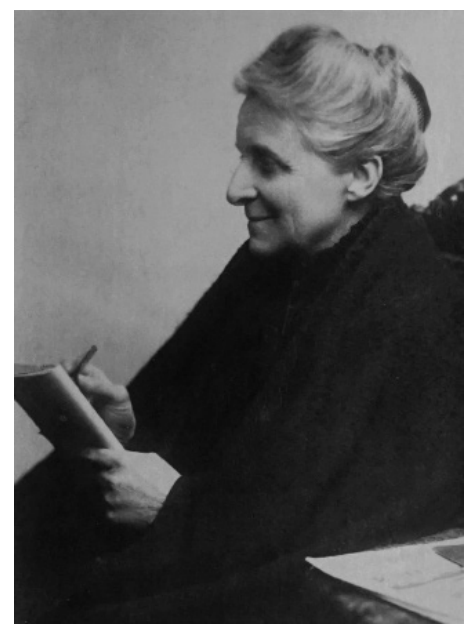

Il. 27. Jadwiga Zamoyska

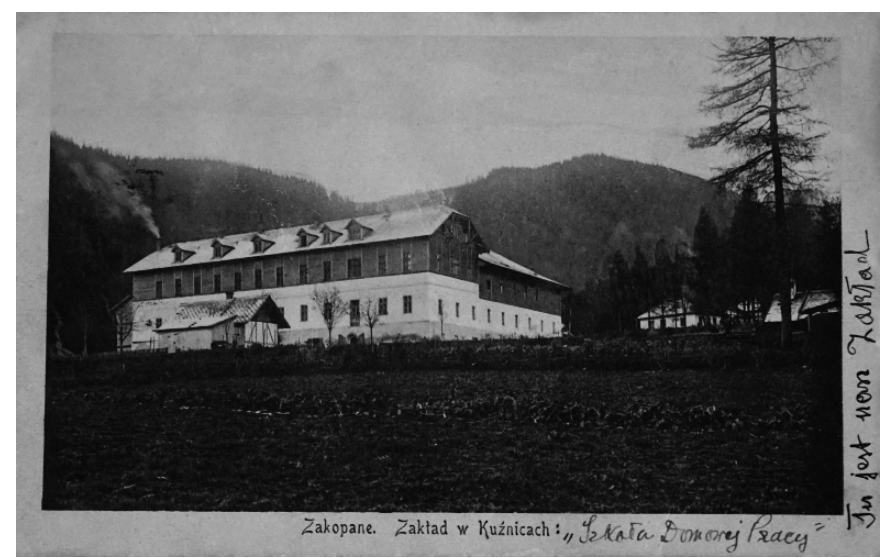

Il. 28. Zakład Kórnicki w Kuźnicach koło Zakopanego

\footnotetext{
${ }^{70}$ ANP, nr top. 253/5-7, 9a, Rodzina Zamoyskich. Jadwiga Generałowa Zamoyska.

${ }^{71}$ ANP, nr top. 253/12, Rodzina Zamoyskich. Andrzej Zamoyski.

${ }^{72}$ ANP, nr top. 253/13, Rodzina Zamoyskich. Zdzisław Zamoyski.

${ }^{73}$ ANP, nr top. 253/14, Rodzina Zamoyskich. Celestyna z Zamoyskich Działyńska.

${ }^{74}$ ANP, nr top. 253/3, Rodzina Zamoyskich. Władysław Zamoyski junior.

${ }^{75}$ ANP, nr top. 253/1, 10a, 11, Rodzina Zamoyskich. Maria Zamoyska.

${ }^{76}$ ANP, nr top. 253/18-34, Rodzina Zamoyskich. Zakład Kórnicki.
} 
Innym przykładem kolekcji mieszanych są 2 pudła dotyczące pracy misjonarzy w Stanach Zjednoczonych Ameryki Północnej i w Australii. Pudełko nazwane Księża Misjonarze w USA zawiera fotografie następujących placówek: w Erie ${ }^{77}$, w Whistestone ${ }^{78}$ oraz w Utica ${ }^{79}$. Jednocześnie spotkamy tam zdjęcia indywidual$\mathrm{ne}^{80} \mathrm{i}$ zbiorcze misjonarzy ${ }^{81}$. W pudełku nazwanym Kościoły $i$ domy Księży Misjonarzy umieszczono fotografie następujących kościołów: św. Michała w Derby ${ }^{82}$, św. Stanisława bpa i męczennika na Brooklynie w Nowym Jorku ${ }^{83}$, św. Stanisława bpa i męczennika w New Haven ${ }^{84}$ oraz w mieście Utica ${ }^{85}$. W tej samej kolekcji zgromadzono również fotografie domów misjonarskich w Erie ${ }^{86}$, na Brooklynie w Nowym Jorku ${ }^{87}$, Whitestone ${ }^{88}$, Derby ${ }^{89}$, w miastach Utica ${ }^{90}$ i Ansonia ${ }^{91}$. Na końcu spotkamy także fotografie przedstawiające kapłanów posługujących w USA i Australiii' ${ }^{22}$.

Ciekawą kolekcją jest zbiór wizerunków Matki Bożej w Polsce. Fotografie zostały uporządkowane według nazw miejscowości ${ }^{93}$.

Ważną kategorią są zbiory przedstawiające kościoły i klasztory. Zbiór fotografii dotyczący kościołów w Polsce podzielono na siedem części. Pierwsza część zawiera zdjęcia kościołów w miejscowościach na litery B-G $\mathrm{G}^{94}$, druga - na litery $\mathrm{H}-\mathrm{K}^{95}$, trzecia część zawiera fotografie kościołów w Krakowie ${ }^{96}$, czwarta - na litery L-M $\mathrm{M}^{97}$, piąta - na litery $\mathrm{N}-\mathrm{S}^{98}$, szósta - na literę $\mathrm{W}^{99}$ oraz siódma na literę $\mathrm{T}^{100}$.

${ }^{77}$ ANP nr top. 0001/2, 7, 10-11,13, 17-18, 22, 24, 26, 28, 29, 31. Zbiór fotografii. Księża Misjonarze św. Wincentego à Paulo w USA (dalej: Misjonarze w USA), Erie.

${ }^{78}$ ANP 0001/14, Misjonarze. w USA. Whistestone.

${ }^{79}$ ANP 0001/32, 35, Misjonarze w USA. Utica.

${ }^{80}$ ANP 0001/3, Misjonarze w USA. Zdjęcia indywidualne.

${ }^{81}$ ANP 0001/1, 4, 5, 8-9, 12, 15-16, 19-21, 23, 25, 30, 33, 36, Misjonarze w USA. Zdjęcia zbiorcze.

${ }^{82}$ ANP, nr top 0002/1, 27-28, Kościoły i domy Księży Misjonarzy (dalej cyt. Kościoły i domy). Kościół św. Michał w Derby.

${ }^{83}$ ANP, nr top. 0002/3, 6, 12, 16-23, Kościoły i domy. Kościół św. Stanisława w Nowym Jorku.

${ }^{84}$ ANP, nr top. 0002/5, 7, Kościoły i domy. Kościół św. Stanisława w New Haven.

${ }^{85}$ ANP, nr top. 0002/14, Kościoły i domy. Kościół w Utica.

${ }^{86}$ ANP, nr top. 0002/8, 29-32, Kościoły i domy. Dom w Erie.

${ }^{87}$ ANP, nr top. 0002/9-10, Kościoły i domy. Dom w Nowym Jorku.

${ }^{88}$ ANP, nr top. 0002/2, Kościoły i domy. Dom w Whitestone.

${ }^{89}$ ANP, nr top. 0002/1,11, 15, 26, Kościoły i domy. Dom w Derby.

${ }^{90}$ ANP, nr top. 0002/24-25, Kościoły i domy. Dom w Utica.

${ }^{91}$ ANP, nr top. 0002/32-41, Kościoły i domy. Dom w Ansonia.

${ }^{92}$ ANP, nr top. 0002/42-65, Księża Misjonarze. Zdjęcia grupowe.

${ }^{93}$ ANP, nr top. 0248/1-83, Zbiór fotografii. Wizerunki Matki Bożej.

${ }^{94}$ ANP, nr top. 0007/1-68, Zbiór fotografii. Kościoły, cz. 1, B-G.

${ }^{95}$ ANP, nr top. 0008/1-60, Kościoły, cz. 2, H-K.

${ }^{96}$ ANP, nr top. 0009/1-77, Kościoły, cz. 3, Kraków.

${ }^{97}$ ANP, nr top. 0010/1-73, Kościoły, cz. 4, L-M.

${ }^{98}$ ANP, nr top. 0011/1-105, Kościoły, cz. 5, N-S.

${ }^{99}$ ANP, nr top. 0012/1-53, Kościoły, cz. 6, W.

${ }^{100}$ ANP, nr top. 0013/1-40, Kościoły, cz. 7, T. 
W osobnym zbiorze zebrano zdjęcia kościołów znajdujących się za granicą ${ }^{101}$. Liczne fotografie przestawiające klasztory i kościoły na ziemiach polskich zebrano w pudełku oznaczonym nr top. $247^{102}$.

Obok wspomnianych powyżej zbiorów fotograficznych zebranych przez ks. Alfonsa Schletza warto dodać, że w Archiwum „Naszej Przeszłości” przechowywane są także albumy. Wśród nich na uwagę zasługują m.in.: album Brat Albert $i$ jego dzieto ${ }^{103}$, album dokumentujący pobyt kleryków misjonarskich w WP ${ }^{104}$, album poświęcony Służebniczkom z Pleszewa ${ }^{105}$ oraz album z okazji wydania XXV tomów „Naszej Przeszłości”106.

Archiwalia, szczególnie fotografie, spoczywające w różnych instytucjach czekają na swojego badacza. Nie są tylko ozdobnikiem czy ilustracją, ale dokumentem, który należy umiejętnie odczytać. Prezentacja zachowanych zbiorów fotograficznych przechowywanych zarówno w Archiwum Polskiej Prowincji Zgromadzenia Księży Misjonarzy, jak i w Archiwum Instytutu Wydawniczego Księży Misjonarzy „Nasza Przeszłość” jest pierwszą próbą przybliżenia szerszej społeczności wiedzy na ich temat. Na pewno ten krótki tekst nie wyczerpuje tematu. Jak już wspomniano, do artykułu wybrano najciekawsze fotografie. Innym kryterium wyboru była także kwestia identyfikacji. Wiele fotografii czeka jeszcze na dokładniejszą analizę. Należy mieć nadzieję, że rozpoczęte prace będą kontynuowane. $Z$ pewnością warto też pomyśleć o digitalizacji, jeśli nie całości, to przynajmniej jakiejś części zbiorów fotograficznych. Podsumowując należy stwierdzić, że zdjęcia zachowane $\mathrm{w}$ archiwach misjonarskich z pewnością mogą wzbogacić naszą wiedzę o ważnych wydarzeniach z historii Kościoła. Przede wszystkim są ważnym świadectwem rozległej działalności misjonarzy św. Wincentego à Paulo w naszym kraju i poza jego granicami.

\section{REFERENCES / BIBLIOGRAFIA}

\section{Źródła archiwalne}

Archiwum Polskiej Prowincji Zgromadzenia Księży Misjonarzy (AMS)

sygn. II.1/010, Bydgoszcz - Akta Domu Zgromadzenia.

sygn. II.1/043, Kraków-Stradom - Akta Domu Zgromadzenia.

${ }^{101}$ ANP, nr top. 246/1-31, Zbiór fotografii. Kościoły zagraniczne.

${ }^{102}$ ANP, nr top. 247/1-172, Zbiór fotografii. Klasztory i kościoły zakonne.

${ }^{103}$ Zawiera dokumentacją fotograficzną wystawy poświęconej osobie Brata Alberta Chmielowskiego przygotowanej przez ks. A. Schletza CM. Por. ANP, nr top. 0552, Album fotograficzny - Brat Albert i jego dzieło. Wystawa.

${ }^{104} \mathrm{~W}$ albumie znalazły się zdjęcia alumnów misjonarskich odbywających służbę w Ludowym Wojsku Polskim. Zbiór zawiera 43 fotografie. Por. ANP, nr top. 1914, Album fotograficzny z przedstawieniami kleryków ze Zgromadzenia Księży Misjonarzy powołanych do służby wojskowej.

${ }^{105}$ Ten album zawiera 67 fotografii przestawiających posługę Sióstr Służebniczek z Pleszewa. Por. ANP, nr top. 1915, Album fotograficzny poświęcony służebniczkom pleszewskim.

106 Album został przygotowany z okazji wydania 25 tomu czasopisma „Nasza Przeszłość” w 1967 r.. Zawiera łącznie 52 fotografie. Por. ANP, nr top. 0553, Album fotograficzny. Sympozjum z okazji wydania XXV tomów „Naszej Przeszłości” (1-2 IV 1967). 
sygn. II.1/044, Kraków-Kleparz - Akta Domu Zgromadzenia.

sygn. II.1/045, Kraków-Nowa Wieś - Akta Domu Zgromadzenia.

sygn. II.1/062, Lwów - Akta Domu Zgromadzenia.

sygn. II.1/068, Milatyn Nowy - Akta Domu Zgromadzenia.

sygn. II.1/075, Odporyszów - Akta Domu Zgromadzenia.

sygn. II.1/108, Tarnów - Akta Domu Zgromadzenia.

sygn. II.1/111, Warszawa - Akta Domu Zgromadzenia.

sygn. II.1/116, Wilno - Akta Domu Zgromadzenia.

sygn. II.1/123, Zakopane - Akta Domu Zgromadzenia.

sygn. II.1/111, Warszawa - Akta Domu Zgromadzenia.

sygn. V/POL 135, Spuścizna ks. Czesława Lewandowskiego.

sygn. V/POL 198, Spuścizna ks. Wilhelma Michalskiego.

sygn. V/POL 236, Spuścizna ks. Konstantego Michalskiego.

sygn. V/POL 259, Spuścizna ks. Józefa Kryski.

sygn. V/POL 305, Spuścizna ks. Hieronima Feichta.

sygn. V/POL 344, Spuścizna ks. Józefa Barona.

sygn. VII.4, Małe Seminarium Zgromadzenia Księży Misjonarzy.

sygn. VII.5, Gimnazjum Wyższe Męskie Zgromadzenia Księży Misjonarzy.

sygn. VII.3, Seminarium Internum Zgromadzenia Księży Misjonarzy.

sygn. VII.7, Zakład Młodzieży Męskiej im. Ks. Kazimierza Siemaszki.

sygn. IX.9, Zdjęcia.

Archiwum Instytutu Wydawniczego Księży Misjonarzy „Nasza Przeszłość” (ANP)

nr top. 0001, Zbiór fotografii. Księża Misjonarze św. Wincentego à Paulo w USA.

nr top. 0002, Zbiór fotografii. Kościoły i domy Księży Misjonarzy.

nr top. 0003, Zbiór fotografii. Fotografie duchownych - indywidualne.

nr top. 0004, Zbiór fotografii. Fotografie różnych osób - indywidualne, cz. 1.

nr top. 0005, Zbiór fotografii. Fotografie różnych osób - indywidualne, cz. 2.

nr top. 0006, Zbiór fotografii. Fotografie różnych osób - zbiorowe.

nr top. 0007, Zbiór fotografii. Kościoły, cz. 1, B-G.

nr top. 0008, Zbiór fotografii. Kościoły, cz. 2, H-K.

nr top. 0009, Zbiór fotografii. Kościoły, cz. 3, Kraków.

nr top. 0010, Zbiór fotografii. Kościoły, cz. 4, L-M.

nr top. 0011, Zbiór fotografii. Kościoły, cz. 5, N-S.

nr top. 0012, Zbiór fotografii. Kościoły, cz. 6, W.

nr top. 0013, Zbiór fotografii. Kościoły, cz. 7, T.

nr top. 0249, Zbiór fotografii. Święci.

nr top. 246, Zbiór fotografii. Kościoły zagraniczne.

nr top. 247, Zbiór fotografii. Klasztory i kościoły zakonne.

nr top. 0250, Zbiór fotografii. Święci i błogosławieni Rodziny Wincentyńskiej.

nr top. 0252, Zbiór fotografii. Biskupi.

nr top. 0253, Zbiór fotografii. Rodzina Zamoyskich.

nr top. 0254, Zbiór fotografii. Misjonarze św. Wincentego à Paulo, cz. 1, A-J.

nr top. 0255, Zbiór fotografii. Misjonarze, cz. 2, K-M.

$\mathrm{nr}$ top. 0256, Zbiór fotografii. Misjonarze, cz. 3, N-S.

nr top. 0257, Zbiór fotografii. Misjonarze, cz. 4, Ś-Z.

nr top. 0248, Zbiór fotografii. Wizerunki Matki Bożej.

nr top. 0552, Album fotograficzny - Brat Albert i jego dzieło. Wystawa.

nr top. 0553, Album fotograficzny. Sympozjum z okazji wydania XXV tomów „Naszej

Przeszłości” (1-2 IV 1967). 
nr top. 1026, Zbiór fotografii. Ksiądz Wacław Szuniewicz CM.

nr top. 1914, Album fotograficzny z przedstawieniami kleryków ze Zgromadzenia Księży

Misjonarzy powołanych do służby wojskowej.

nr top. 1915, Album fotograficzny poświęcony służebniczkom pleszewskim.

\section{Opracowania}

Janaczek Stanisław, Powstanie i organizacja Krakowskiej Prowincji Księży Misjonarzy (1865-1914), „Nasza Przeszłość”, 86 (1996) s. 361-432.

Janczak Łukasz, Wspomnienie ostatnich chwil istnienia w Polsce Zgromadzenia Księży Misjonarzy w Domu Głównym przy kościele św. Krzyża w Warszawie, „Roczniki Obydwóch Zgromadzeń", (1900) s. 11-20.

Kałamarz Wojciech, Muzyka u Misjonarzy, Muzyka u misjonarzy. Wkład Zgromadzenia Księży Misjonarzy św. Wincentego a Paulo, Kraków 2009.

Katalog zabytków sztuki w Polsce, t. 4, Miasto Kraków, cz. 5, Kazimierz i Stradom, Kościoty i klasztory, 2, red. I. Reduch-Samkowa, J. Samek, Warszawa 1994.

Lange Magdalena, Archiwum Zgromadzenia Księży Misjonarzy w Krakowie, „Archiwariusz. Biuletyn Archiwum Archidiecezjalnego w Poznaniu”, (2007) nr 3 [druk 2009], s. $130-132$.

Michalewicz Jerzy, Katalog archiwum polskiej prowincji Zgromadzenia Księży Misjonarzy św. Wincentego a Paulo, t. 1, Kraków 2014.

Michalewicz Jerzy, Katalog archiwum polskiej prowincji Zgromadzenia Księży Misjonarzy św. Wincentego a Paulo, t. 2, Kraków 2018.

Misja Polska w pismach Wincentego a Paulo i Ludwiki de Marillac, t. 1, Kraków 2010.

Misjonarze św. Wincentego a Paulo w Polsce (1651-2001), t. 1, Dzieje, red. S. Rospond, Kraków 2001.

Umiński Wacław, Archiwum Prowincji Polskiej Zgromadzenia Księży Misjonarzy w Krakowie, „Archiva Ecclesiastica”, (2005) nr 2, s. 67-69.

Umiński Wacław, Polska Prowincja Zgromadzenia Księży Misjonarzy w latach 19181939, Kraków 2009.

Umiński Wacław, Schletz Alfons, Encyklopedia katolicka, t. 17, red. E. Gigilewicz, Lublin 2012, kol. 1243-1244.

Umiński Wacław, Gromadzenie i charakterystyka zbiorów w Archiwum „Naszej Przeszłości”, w: Zabezpieczanie i udostępnianie archiwalnych zasobów kościelnych, red. A. Laszuk, Warszawa 2016, s. 148-158.

Umiński Wacław, Konwikt Teologiczny Świętego Krzyża w Warszawie w latach 19181939, Kraków 2017. 


\title{
SELECTED PHOTOGRAPH COLLECTIONS IN THE ARCHIVES OF THE POLISH PROVINCE OF THE CONGREGATION OF THE MISSION IN CRACOW AND THE ARCHIVES OF THE PUBLISHING INSTITUTE OF THE CONGREGATION OF THE MISSION ,NASZA PRZESZLOŚĆ” IN CRACOW
}

\begin{abstract}
The aim of this article is to present some of the photograph collections accumulated in the Archives of the Polish Province of the Congregation of the Mission in Cracow and the Archives of the Publishing Institute of the Congregation of the Mission „Nasza Przeszłość” in Cracow. Both institutions, apart from records, surveying-cartographic and technical materials, hold photographs. These include mainly single photographs documenting the life of members of the Congregation of the Mission and the history of its missionary outposts. There are also albums and boxes which contain theme-related photographs. In most cases it is not possible to identify their authors, except for the collection held in the „Nasza Przeszłość” Archives. It was accumulated by its founder, Professor Rev. Alfons Schletz CM, who for many years gathered various photographs, which he arranged into a number of different collections.

Keywords: Vincentians; the Archives of the Polish Province of the Congregation of the Mission; the Archives of the Publishing Institute „Nasza Przeszłość” photographs; albums; collections
\end{abstract}

